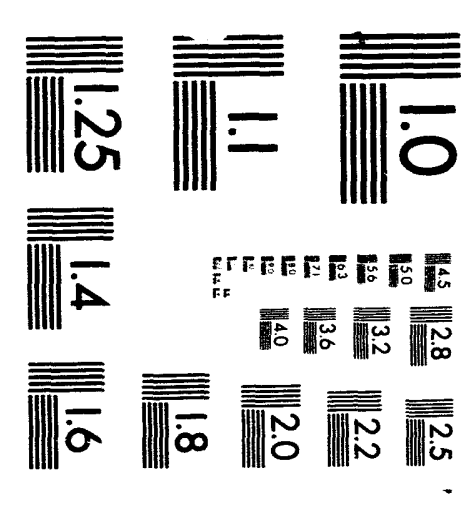




\title{
HOT COAL GAS DESULFURIZATION WITH MANGANESE-BASED SORBENTS
}

Progress Report for the Period April 1, 1993 to June 30, 1993

\author{
By \\ M. T. Hepworth, Department of Civil and Mineral Engineering \\ University of Minnesota, Minneapolis, MN
}

July $15,1993$.

Work Performed Under Contract No.: DE-AC21-92MC29246

For:

U. S. Department of Energy

Morgantown Energy Technology Center

Morgantown, West Virginia

\section{DISCLAIMER}

This report was prepared as an account of work sponsored by an agency of the United States Government. Neither the United States Government nor any agency thereof, nor any of their employees, makes any warranty, express or implied, or assumes any legal liability or responsibility for the accuracy, completeness, or usefulness of any information, apparatus, product, or process disclosed, or represents that its use would not infringe privately owned rights. Reference herein to any specific commercial product, process, or service by trade name, trademark, ence does not necessarily constitute or imply its endorsement, recommendation, or favoring by the United States Government or any agency thereof. The views and opinions of authors expressed herein do not necessarily state or reflect those of the United States Government or any agency thereof.

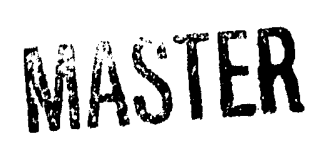




\begin{abstract}
The focus of work being performed on Hot Coal Gas Desulfurizativa at the Morgantown Energy Technology Center is primarily in the use of zinc ferrite and zinc titanate sorbents; however, prior studies at the U. S. Steel Fundamental Research Laboratories in Monroeville, PA, by E. T. Turkdogan ${ }^{1}$ indicated that an alternate sorbent, manganese dioxidecontaining ore in mixture with alumina (75 wt\% ore $+25 \mathrm{wt} \% \mathrm{Al}_{2} \mathrm{O}_{3}$ ) may be a viable alternative to zinc-based sorbents. Manganese, for example, has a lower vapor pressure in the elemental state than zinc hence it is not as likely to undergo depletion from the sorbent surface upon loading and regeneration cycles. Also manganese oxide is less readily reduced to the elemental state than iron hence the range of reduction potentials for oxygen is somewhat greater than for zinc ferrite. In addition, thermodynamic analysis of the manganese-oxygen-sulfur system shows it to be less amenable to sulfation than zinc ferrite. Potential also exists for utilization of manganese higher temperatures than zinc ferrite or zinc titanate.

This report gives the thermodynamic background for consideration of manganese-based sorbents as an alternative to zinc ferrite. To date the work which has been in progress for nine months is limited at this stage to thermogravimetric testing of four formulations of manganese-alumina sorbents to determine the optimum conditions of pelletization and induration to produce reactive pellets.
\end{abstract}

\title{
INTRODUCTION
}

Zinc ferrite and zinc titanate are being developed as regenerable sorbents capable of removing hydrogen sulfide from hot coal gases. Utilization is only about $10 \%$ sulfur loading, however, and zinc ferrite tends to spall and be limited in temperature.

Manganese-based sorbents combined with alumina to form indurated pellets hold promise of being highly-effective, inexpensive, regenerable sorbents for hot fuel gases. These sorbents are effective in making very strong (>50 pounds crush strength for a 4-mm pellet), which can be loaded and regenerated at higher temperatures than zinc ferrite (which is limited to about 1100 to $1200^{\circ} \mathrm{F}$ ), and which appear to be capable of improved loading with

${ }^{1}$ Turkdogan, E. T. and Olsson, R. G.: "Desulfurization of Hot Reducing Gases with Manganese Oxide Pellets", Proceedings Third International Iron and Steel Congress ASM Metals Park, Ohio, 1979, pp.277-288. 
each cycle and also load sulfur to a higher weight of pellet. The thermodynamics for sulfur removal by manganese predicts sulfur removal to terminal levels (in terms of the over-pressure of hydrogen sulfide) somewhat less favorable than can be accomplished with zinc oxide; however, zinc can be reduced under coal gasification conditions and tends to volatilize, limiting the temperatures for which desulfurization can be effectively accomplished to values less than $700^{\circ} \mathrm{C}^{2,3}$ Also the capabilities for regeneration of manganese pellets (with an alumina filler@75wt\% Comilog ore, 25 wt\% $\mathrm{Al}_{2} \mathrm{O}_{3}$ ) under oxidizing conditions may be superior to those of zinc ferrite in that they can be loaded from a reducing gas and regenerated at higher temperatures (regeneration up to $1300^{\circ} \mathrm{C}$ ). Upon regeneration of the loaded sorbent, sulfur can be obtained from the off-gases by combination of the products of the regeneration: hydrogen sulfide and sulfur dioxide or alternatively, a high strength sulfur dioxide gas mixture suitable for sulfuric acid manufacture can be produced.

A significant domestic source of manganese in Minnesota is being explored for an in situ leach process which has potential for producing large tonnages of solutions which may be ideal for precipitation and recovery of pure manganese as a carbonate in a reactive form. ${ }^{4}$

In this current program the following studies are being addressed:

- $\quad$ preparation and characterization of manganese-based sorbents,

- the thermodynamics and kinetics of sulfur removal from hot fuel gases by this sorbent, and

- the cyclic loading and regeneration of the sorbent by oxidation and recovery of the sulfur.

This study will update earlier studies made at the laboratories of U. S. Steel undertaken by Dr. E. T. Turkdogan. Those studies, which utilized a manganese ore blended with alumina, were successful in achieving

\footnotetext{
${ }^{2}$ Woods, M. C., Gangwal, S. K., Jothimururugesan, K., and Harrison, D. P.: "Reaction between $\mathrm{H}_{2} \mathrm{~S}$ and Zinc Oxide-Titanium Oxide Sorbents. 1 Single-Pellet Kinetic Studies", I \& EC Research, 1990, 29, p. 1160-1167.

${ }^{3}$ Hepworth, M.T. and Jha, M.C., "Enhanced Durability and Reactivity for Zinc Ferrite Desulfurization Sorbent," Proceedings of the Eighth Annual Gasification and Gas Stream Cleanup Systems Contractors Review Meeting, Vol. 1, DOE/METC-88/6092.

${ }^{4}$ Hepworth, M. T.: Selective Mining Methods for Minnesota, MN Initiative Project: Manganese Recovery from In-Situ Leach Liquors, Final Report to U. S. Bureau of Mines from the Mineral Resources Research Center 1992.
} 
desulfurization from reducing gases. This earlier work was not undertaken with the gas mixtures which are proposed for this study, nor were the manganese formulations the same as are planned; however, the initial success of the work of Turkdogan indicates that significant progress can be made in moving forward toward developing a high-temperature regenerable sorbent.

The developed information will be of value to METC in determining whether or not a manganese-based regenerable sorbent holds real promise for sulfur cleanup of hot fuel gases. This information is necessary before pilot-scale testing leading to commercial development is undertaken.

\section{Current Status of Test Work:}

The following tasks have been completed ( $\star$ ), are being undertaken ( $\downarrow)$, or will be undertaken ( $\square$ ) during the next 15 months of the contract:

1) ( $\star$ Providing Information Required for the National Environmental Policy Act;

2) ( $\$$ Sorbent Preparation and Characterization Tests on Individual Pellets

3) (४)Provision for Bench-Scale Test Unit

4) (1)Bench-Scale Testing

5) (四)Data Analysis

The program consists of the following studies:

- Establish the thermodynamic feasibility for the use of manganese-based sorbents for the removal of sulfur in comparison with other oxide systems.

- Prepare and characterize manganese sorbent pellets. Initial characterization is based upon strength and surface area.

- Determine the comparative kinetics of loading and regeneration of individual sorbent pellets via thermo-gravimetric analysis (TGA). Preliminary TGA tests are showing that sorbents prepared with the organic binder, dextrin, on Comilog ore appear to offer the best combination of strength, reactivity, and capacity

- Build a two-inch reactor fixed-bed test unit. This unit is currently built and being tested.

- Perform bench-scale tests on the optimum sorbent pellets in a two-inch diameter reactor. 


\section{THERMODYNAMIC CONSIDERATIONS}

This section considers the reaction equilibria in the sulfidation and regeneration cycles. There are four oxides of manganese: $\mathrm{MnO}, \mathrm{Mn}_{3} \mathrm{O}_{4}$, $\mathrm{Mn}_{2} \mathrm{O}_{3}$, and $\mathrm{MnO}_{2}$. Figure 1 gives the oxygen potential as a function of temperature for converting oxides with superimposed equilibrium $\mathrm{CO}_{2} / \mathrm{CO}$ ratios in the gas phase. As indicated by the dotted lines, $\mathrm{MnO}$ cannot be reduced to metallic manganese by $\mathrm{CO}$ or $\mathrm{H}_{2}$ because of the unavoidable presence of trace amounts of $\mathrm{CO}_{2}$ and $\mathrm{H}_{2} \mathrm{O}$ in the reducing gas. In addition, the higher oxides of manganese are readily reduced to $\mathrm{MnO}$ even in very slightly reducing atmospheres.

The reducing gas is desulfurized by $\mathrm{MnO}$ according to the following reaction:

$$
\mathrm{MnO}+\mathrm{H}_{2} \mathrm{~S}=\mathrm{MnS}+\mathrm{H}_{2} \mathrm{O}
$$

The equilibrium ratio of $\mathrm{H}_{2} \mathrm{O} / \mathrm{H}_{2} \mathrm{~S}$ for this reaction, as determined by Turkdogan and Olsson ${ }^{1}$, is given by:

$$
\log \left[\frac{p H_{2} \mathrm{O}}{p H_{2} \mathrm{~S}}\right]=\frac{3330}{T}-0.310
$$

In the desulfurization of hot reducing gases by MnO-based pellets, the extent of desulfurization achieved depends on the temperature and gas composition. The residual $\mathrm{H}_{2} \mathrm{~S}$ concentration in the desulfurized gas, calculated, using SOLGASMIX ${ }^{5}$, for the conditions of gas-solid equilibrium in the reactor, is shown in Figure 2 as a function of temperature for various typical oxygen-blown and air-blown gasifier gases ${ }^{5}$ the compositions of which are reported in Appendix A. It is seen from this figure that the lower the operating temperature and the lower the $\mathrm{H}_{2} \mathrm{O} / \mathrm{H}_{2} \mathrm{~S}$ ratio, the lower is the residual sulfur in the cleaned gas.

Most sulfur sorbents can be regenerated after sulfidation by reacting the sulfide with a $\mathrm{CO}_{2}-\mathrm{H}_{2} \mathrm{O}$ mixture. The decomposition of $\mathrm{MnCO}_{3}$ to $\mathrm{MnO}$ occurs at $343^{\circ} \mathrm{C}$ with $\mathrm{CO}_{2}$ evolving at one atmosphere. Because of this undesirable equilibrium condition, $\mathrm{MnO}$ cannot be regenerated by using a $\mathrm{CO}_{2}-\mathrm{H}_{2} \mathrm{O}$ mixture.

${ }^{5}$ SolgasMix Computer Program version by Morris, A. E., Flynn, H., and Carter, D: "Using the UMR Stepsol Package," Version 4.0 Released Feb., 1, 1990, Generic Mineral Technology Center for Pyrometallurgy, University of Missouri, at Rolla. 
If the regeneration gas consisted of pure $\mathrm{H}_{2} \mathrm{O}$ or $\mathrm{CO}_{2}$, the regeneration can be represented by the following reactions:

$$
\begin{aligned}
& \mathrm{MnS}+3 \mathrm{H}_{2} \mathrm{O}=\mathrm{MnO}+3 \mathrm{H}_{2}+\mathrm{SO}_{2} \\
& \mathrm{MnS}+3 \mathrm{CO}_{2}=\mathrm{MnO}+3 \mathrm{CO}+\mathrm{SO}_{2}
\end{aligned}
$$

However, these two routes are not practically feasible because of the low $\mathrm{SO}_{2}$ concentration in the product gases.

According to the above analysis, the regeneration of $\mathrm{MnO}$ must be oxidative, i.e., involving air, pure oxygen, oxygen-enriched air, oxygendeficient air, or $\mathrm{SO}_{2}-\mathrm{O}_{2}$ mixture. It follows that we should consider the phase equilibria in the $\mathrm{Mn}-\mathrm{S}-\mathrm{O}$ system in the temperature range of interest to regeneration. Figure 3 is a stability equilibrium diagram for the $\mathrm{Mn}-\mathrm{S}-\mathrm{O}$ system at 800,1000 , and $1200^{\circ} \mathrm{C}$. The logarithms of the equilibrium $\mathrm{SO}_{2}$ and $\mathrm{O}_{2}$ partial pressures represent the ordinate and abscissa, respectively.

As can be seen from Figure 3, the stoichiometric regeneration of the oxide by reacting the sulfide with an $\mathrm{O}_{2}$-containing regeneration gas at atmospheric pressure, the partial pressure of $\mathrm{SO}_{2}$ in the product gas can never be high enough to form $\mathrm{MnSO}_{4}$ at temperatures above $900^{\circ} \mathrm{C}$. Consequently, under these conditions the overall reaction is:

$$
\mathrm{MnS}+5 / 3 \mathrm{O}_{2}=1 / 3 \mathrm{Mn}_{3} \mathrm{O}_{4}+\mathrm{SO}_{2}
$$

The above reaction is thermodynamically favorable and proceeds essentially to completion in the temperature range 900 to $1200^{\circ} \mathrm{C}$. Thus, the oxygen in the reactant gas is virtually converted to $\mathrm{SO}_{2}$. For example, if an $\mathrm{O}_{2}-\mathrm{SO}_{2}$ gas mixture is used, the product gas would be pure $\mathrm{SO}_{2}$ for complete conversion. The regenerated manganese oxide would be in the form of $\mathrm{Mn}_{3} \mathrm{O}_{4}$ which should be subsequently reduced to $\mathrm{MnO}$ prior to recycle to the sulfidation stage. The maximum temperature of both sulfidation and regeneration can be as high as $1232^{\circ} \mathrm{C}$, the eutectic temperature of the pseudo-binary system $\mathrm{MnO}-\mathrm{MnS}$.

It should be noted, however, that the oxidative regeneration of the oxide with the fore-mentioned gas is highly exothermic. Practical problems may be encountered in the control of the reactor temperature. This may be overcome by using a $\mathrm{CO}_{2}-\mathrm{H}_{2} \mathrm{O}-\mathrm{O}_{2}$ gas mixture where, in addition to the exothermic oxidation of $\mathrm{MnS}_{\text {by }} \mathrm{O}_{2}$, additional endothermic reactions may occur: 


$$
\begin{aligned}
& \mathrm{MnS}+3 \mathrm{CO}_{2}=\mathrm{MnO}+3 \mathrm{CO}+\mathrm{SO}_{2} \\
& \mathrm{MnS}+3 \mathrm{H}_{2} \mathrm{O}=\mathrm{MnO}+3 \mathrm{H}_{2}+\mathrm{SO}_{2} \\
& \mathrm{MnO}+1 / 6 \mathrm{O}_{2}=1 / 3 \mathrm{Mn}_{3} \mathrm{O}_{4} \\
& 2 \mathrm{CO}+\mathrm{SO}_{2}=1 / 2 \mathrm{~S}_{2}+2 \mathrm{CO}_{2} \\
& 3 \mathrm{CO}+\mathrm{SO}_{2}=\mathrm{COS}+2 \mathrm{CO}_{2} \\
& 3 \mathrm{H}_{2}+\mathrm{SO}_{2}=\mathrm{H}_{2} \mathrm{~S}+2 \mathrm{H}_{2} \mathrm{O} \\
& \mathrm{CO}_{2}+\mathrm{H}_{2}=\mathrm{H}_{2} \mathrm{O}+\mathrm{CO}
\end{aligned}
$$

$\mathrm{MnO}$ is converted to $\mathrm{Mn}_{3} \mathrm{O}_{4}$ because of the availability of $\mathrm{O}_{2}$ in the gas.

\section{EXPERIMENTAL PROCEDURES AND RESULTS}

Since the prior studies by Turkdogan and Olsson were conducted on a manganese ore (Comilog ore), the starting point for the present investigation is using similar materials for comparison. Then manganese oxide derived from pure carbonate, similar to that which would be recovered from in-situ mining is studied. Accordingly, the following materials are being utilized: (Chemical analyses are reported in Appendix B)

- $\quad \mathrm{MnO}_{2}$ Comilog ore (Africa);

- Ultrafine $\mathrm{MnCO}_{3}$ (93-95\%) (Chemetals, Inc.);

- $\quad$ Alundum (96.6\% $\mathrm{Al}_{2} \mathrm{O}_{3}$ ) (Norton Materials, Inc.);

- Bentonite, inorganic binder (Aldrich Chemical Co.); and

- Dextrin, an organic binder.

\section{Pelletization:}

Blends consist of a manganese-containing compound, an alumina-based matrix, and a binder, based on desired compositions determined on a dry weight-percent basis. The amount of binder used should be as low as possible, not only to save on the cost, but also to provide a greater amount of chemically active sorbent in a given volume of packed bed. After each blend is mixed, an appropriate amount of water is added prior to pelletizing.

Pelletization is accomplished using a balling tire at a $40-60^{\circ}$ inclination and a rotational speed of $40-50 \mathrm{rpm}$. Feed is prepared by adding binder to the dry mix, and mulling while adding water slowly to form a cohesive state. Moisture is added in controlled quantities via hand spray to the mix which is then passed through a 10 -mesh sieve.

Seeds are prepared by moistening the tire interior, wiping it clean, and then slowly sprinkling about $7 \mathrm{wt} . \%$ of the prepared, moist feed mixture 
into the tire rotating at $50 \mathrm{rpm}$. When seeds begin to form, they are removed and sieved through a 6-mesh screen. Fines are returned to the tire. This procedure is continued until all the feed has been agglomerated. Ideally, the seeds range between 2 to $3 \mathrm{~mm}$ in diameter.

In the subsequent balling operation, the seeds are returned to the rotating tire and sprayed to the glistening point (a visual observation of surface appearance). Spray is applied as needed to reach the incipient glistening point during the balling operation. When all the loose feed has been assimilated, the product is removed and screened to retain the 7 to $10-\mathrm{mm}$ fraction. The moist pellets are stored in sealed containers pending evaluations.

The above two-step pelletizing procedure, in which seeds are first prepared, largely eliminates further seed formation during the balling step and the presence of undersized balls in the final gross product. The required moisture content for the feed depends on its average density. Balling is known to be optimal at 30 to $35 \%$ moisture on a volume basis, i.e., the approximate void fraction in dried pellets. For $33 \%$ moisture on a volume basis, it can be shown that the required amount of water to be added is given by the following equation:

$$
W t . \% H_{2} O=\frac{100}{\left[1+\frac{67}{33} *\left(\rho_{A v}\right)\right]}
$$

where $\rho_{A v}$ is the average density of the feed.

The average ball size in the gross product is dependent upon the number of seeds and the amount of new feed added to them. If too few seeds are used, not all the feed can be added; if too many, the feed may run out before the desired ball size is reached.

Following the above procedure, four formulations have been prepared:

1) $75 \mathrm{~g}$ comilog ore; $25 \mathrm{~g}$ alundum; $10 \mathrm{~g}$ dextrin

2) $75 \mathrm{~g}$ comilog ore; $25 \mathrm{~g}$ alundum; $2 \mathrm{~g}$ bentonite

3) $121 \mathrm{~g}$ manganese carbonate; $25 \mathrm{~g}$ alundum; $10 \mathrm{~g}$ dextrin

4) $121 \mathrm{~g}$ manganese carbonate; $25 \mathrm{~g}$ alundum; $2 \mathrm{~g}$ dextrin. (Note that calcination of manganese carbonate reduces its mass from $121 \mathrm{~g}$ to $75 \mathrm{~g}$ manganese oxide).

Induration:

The pellets were dried to a constant weight at $110^{\circ} \mathrm{C}$ and then indurated. Induration is being conducted for a 12-hour cycle in air: heating from $25^{\circ} \mathrm{C}$ 
to $300^{\circ} \mathrm{C}$ over a period of $1 \mathrm{hr}$; heating from $300^{\circ} \mathrm{C}$ to $400^{\circ} \mathrm{C}$ over a period of 4 hours $\left(343^{\circ} \mathrm{C}\right.$ is the decomposition temperature of manganese carbonate); heating from $400^{\circ} \mathrm{C}$ to $1200^{\circ} \mathrm{C}$ over a period of $5 \mathrm{hrs}$; and then holding at $1200^{\circ} \mathrm{C}$ for two hours for the ore samples and $1250^{\circ} \mathrm{C}$ for the carbonate samples; furnace cool overnight to room temperature. The room-temperature crush strength of the pellets has been found to be as high as 82 pounds dead weight (on a pellet of $5-8 \mathrm{~mm}$ in diameter).

The following are some preliminary data obtained using the above combinations of raw materials:

Formulation 1

- Moisture content of pellets: $12 \%$

- Room Temperature green crush strength : $5.5 \mathrm{lbs}$

- Induration at $\mathrm{T}=1200^{\circ} \mathrm{C}$ : weight loss was $13 \%$

- Room temperature crush strength of indurated pellets: $72 \mathrm{lbs}$.

Formulation 2

- $\quad$ Moisture content of pellets :10.5\%

- Room Temperature green crush strength : $6.5 \mathrm{lbs}$

- Induration at $\mathrm{T}=1200^{\circ} \mathrm{C}$ : weight loss was $11 \%$

- Room temperature crush strength of indurated pellets: 85 lbs

Formulation 3

- $\quad$ Moisture content of pellets : $12.5 \%$

- Room Temperature green crush strength : $3 \mathrm{lbs}$

- Induration at $\mathrm{T} 1250^{\circ} \mathrm{C}$ : weight loss was $40 \%$

- Room temperature crush strength of indurated pellets: $35 \mathrm{lbs}$.

Formulation 4

- $\quad$ Moisture content of pellets :11\%

- Room Temperature green crush strength : 3.5 lbs

- Induration at $\mathrm{T}=1250^{\circ} \mathrm{C}$ : weight loss was $38 \%$

- Room temperature crush strength of indurated pellets: $\mathbf{4 2}$ lbs

\section{Pellet Porousity and Surface Area}

BET surface area tests on indurated pellets have shown them to hae a surface area less than $0.2 \mathrm{~m}^{2} / \mathrm{gm}$, which is below the sensitivity of our equipment. We are attempting to increase pellet surface area; however, TGA testing at this time does show them to be about as reactive as the zinv titanate pellets which have been studied by other investigators. 
Porousity tests made by combination of aqueous picnometry on crushed pellets from formulation 2 in combination with mercury picnometry showed the pellets to have a porousity of about $36 \%$

\section{Scoping Tests via TGA on Pellet Reactivity:}

The reduction, sulfidation, and regeneration behavior of the above four formulations of manganese-based sorbents are being studied via TGA in alternate loading and regeneration cycles in scoping tests on individual pellets. The selection criteria for a "good" sorbent will be based upon strength (a minimum of 15 pounds dead weight on a $5-\mathrm{mm}$ diameter pellet), surface area $\left(>2 \mathrm{~m}^{2} / \mathrm{g}\right.$ ), sulfur capacity ( $>70 \%$ conversion of $\mathrm{MnO}$ to $\mathrm{MnS}$ ), resistance to breakdown upon cycling, rate of loading (90\% loaded in a 3 vol\% $\mathrm{H}_{2} \mathrm{~S}$ atmosphere within 120 minutes), and rate of regeneration (90\% regeneration in air within 10 minutes).

To date, all four formulations appear to satisfy these criteria; however, multiple cyclic loading has not yet been completed beyond three cycles per pellet.

The temperature ranges for loading which are being studied are between $600^{\circ} \mathrm{C}$ to $1000^{\circ} \mathrm{C}$; and for regeneration between $1050^{\circ}$ to $1200^{\circ} \mathrm{C}$. An optimum induration temperature for the dried pellets appears to be $1200^{\circ} \mathrm{C}$ for the comilog ore to $1250^{\circ} \mathrm{C}$ for the $\mathrm{MnCO}_{3}$.

Gas atmospheres in the preliminary loading tests on individual pellets are confined to pure hydrogen gas spiked with 3 vol\% hydrogen sulfide.

Regeneration tests are limited to gas atmospheres containing air plus nitrogen. The provisional gas atmosphere for the fixed-bed loading tests is a gas composition simulating the Tampella $\mathrm{U}$ gas composition: $24.33 \% \mathrm{CO}$, $5.16 \% \mathrm{CO}_{2}, 13.19 \% \mathrm{H}_{2}, 5.35 \% \mathrm{H}_{2} \mathrm{O}, 0.118 \% \mathrm{H}_{2} \mathrm{~S}, 5.35 \% \mathrm{H}_{2} \mathrm{O}$, balance nitrogen, with the exception that the hydrogen sulfide level will be varied between 1 and $3 \%$ to achieve earlier break-through.

The Stanton-Redcroft unit which we have currently been using enables us to conduct only single-pellet tests; however, a Cahn micro-balance system has been made available to this study at the U.S. Bureau of Mines, Twin Cities Research Laboratories. This unit which is equipped with on-stream gas analysis can handle up to five pellets for each test. The use of this unit should accellerate testing.

Results of Scoping Tests (TGA): Some representative scoping loading tests conducted on ca. $150 \mathrm{mg}$ pellets using pure hydrogen followed by hydrogen containing 3 vol $\% \mathrm{H}_{2} \mathrm{~S}$ are 
summarized in Figures 4-7, which show the reduction and sulfidation kinetics of several of the formulations. All tests were for gas flow rates of $150 \mathrm{ml}$ per minute, which represents an average superficial gas velocity of $35 \mathrm{~cm}$ per second corrected for a temperature of $800^{\circ} \mathrm{C}$. Under these conditions, the maximum rate of delivery of sulfur to the pellet during the sulfidation portion of the test is at least $5 \mathrm{mg} /$ minute, which is sufficiently high so as to assure that the kinetics are not controlled by the rate of input of sulfur to the system but rather are a result of either surface reaction kinetics or diffusion within the pellet.

In these figures, the weight of the pellet divided by its initial weight $\left(\mathrm{W} / \mathrm{W}_{\mathrm{o}}\right)$ is plotted against time in minutes for individual pellets tested at several temperatures. Figure 4 is for formulation 2 (i.e., Comilog ore plus alundum bonded with bentonite). The horizontal dashed lines on this figure drawn to represent the following calculated conditions: The line passing through 1.000 on the ordinate is for the initial mass ratio of the indurated pellet prior to reduction with the manganese represented by the formula $\mathrm{Mn}_{3} \mathrm{O}_{4}$ (sesqui-oxide). The lowest line represents the mass fraction for this formulation at which all the sesqui-oxide is converted to the monoxide $(\mathrm{MnO})$. The top line represents the mass fraction which would occur upon complete reaction of the monoxide to the monosulfide (MnS). For the test "TGA Run 2-10-1" conducted at $700^{\circ} \mathrm{C}$, (represented by open triangles) the first thirty minutes of the test are for exposure of the pellet to pure hydrogen (no $\mathrm{H}_{2} \mathrm{~S}$ ). The start of the test was established by switching the gas atmosphere from nitrogen, which was used as an inert gas blanket during heat up of the pellet to hydrogen. The incubation period of 2 minutes did not appear for higher temperatures. The sharp loss of weight following this period represents the rapid reduction of the sesquioxide to the monoxide. The drop in mass ratio below the calculated composition of the monoxide may be a result of sub-oxide formation. After 30 minutes, when no further significant weight loss occurred the gas mixture was switched to hydrogen containing 3 vol $\% \mathrm{H}_{2} \mathrm{~S}$. The initial rapid weight gain followed by a more gradual rise after the first ten minutes occurred over the next hour.

The second plot for Run 1-15-1 conducted for another pellet of the same formulation at $900^{\circ} \mathrm{C}$ (solid squares) showed no initial incubation period and a similar reduction to the composition $\mathrm{MnO}$ occurring over a 40 minute period, after which the gas atmosphere was switched to the sulfidizing gas. For this higher temperature test, a more rapid rate of rise in weight is noted and a more rapid asymptotic approach to the composition $\mathrm{MnS}$ occurred over the subsequent 60 -minute period for sulfidation. 
Figure 5 includes the prior two tests on a time axis extended to 150 minutes. Also included in this figure is loading data for Run 4-12-1 for formulation 1 (Comilog ore plus alumina and dextrin) conducted at $800^{\circ} \mathrm{C}$ (half-filled circles). The time to achieve reduction of the sesqui-oxide to the monoxide is only 15 minutes. At this time the gas mixture was changed to sulfidizing and rose rapidly to become congruent with the Run 1-15-1 for formuln:iun 2 conducted at $900^{\circ} \mathrm{C}$. This test was continued for 130 minutes. The test results show an asymptotic approach to the MnS line. The gas mixture was then shifted to nitrogen plus air for a first regeneration starting at 120 minutes. The rapid drop in mass, associated with the conversion of the sulfide to the monoxide occurred over the next hour with an asymptotic approach to the initial mass associated with the sesquioxide composition.

Figure 6 compares the four formulations at tests conducted at $800^{\circ} \mathrm{C}$. The comparison is made after a prior reduction step. The curves represent in descending vertical order formulations 1,2,3,and 4. In comparing these four formulations, the dextrin binder is somewhat superior to the bentonite binder with respect to kinetics and ultimate loading capacity. This effect may be a result of the increase in porosity of the pellet bound with an organic binder (dextrin) compared with the inorganic binder (bentonite). As the pellet is indurated, the dextrin would be expected to volatilize leaving a greater interconnected porosity.

As of this writing (6/14/93), only one formulation (\#1) has been subjected to limited cyclic testing in which loading is followed by regeneration in an air atmosphere at $1050^{\circ} \mathrm{C}$. Figure 7 for loading and regeneration gives the results of cyclic testing for three cycles. The reduction in rate and capacity over three cycles is barely perceptible within the precision of the equipment.

\section{SUMMARY AND CONCLUSIONS TO DATE}

Four sorbent formulations have been prepared using comilog ore and manganese carbonate as starting materials in combination with alumina. Both dextrin and bentonite have been employed as bonding materials for pellet formation; however, dextrin, which appears to produce favorable porosity and is volatilized upon induration is a preferred binder. All pellets made met strength requirements. The carbonate required an induration temperature of $1250^{\circ} \mathrm{C}$; whereas, the oxide (ore) requires an induration temperature of $1200^{\circ} \mathrm{C}$.

Limited cyclic testing on individual pellets showed very little decline in kinetics and sorbent capacity over three cycles of loading and regeneration. 


\section{FUTURE WORK PLANS}

Future work will continue characterization tests on individual pellets followed by bench scale testing in a two-inch reactor of the optimum pellet formulation as determined by on-going TGA testing.

- Prepare and characterize manganese sorbent pellets. Initial characterization is based upon strength and surface area.

- Determine the comparative kinetics of loading and regeneration of individual sorbent pellets via thermogravimetric analysis (TGA).

- Perform bench-scale tests on the optimum sorbent pellets in a two-inch diameter reactor. 


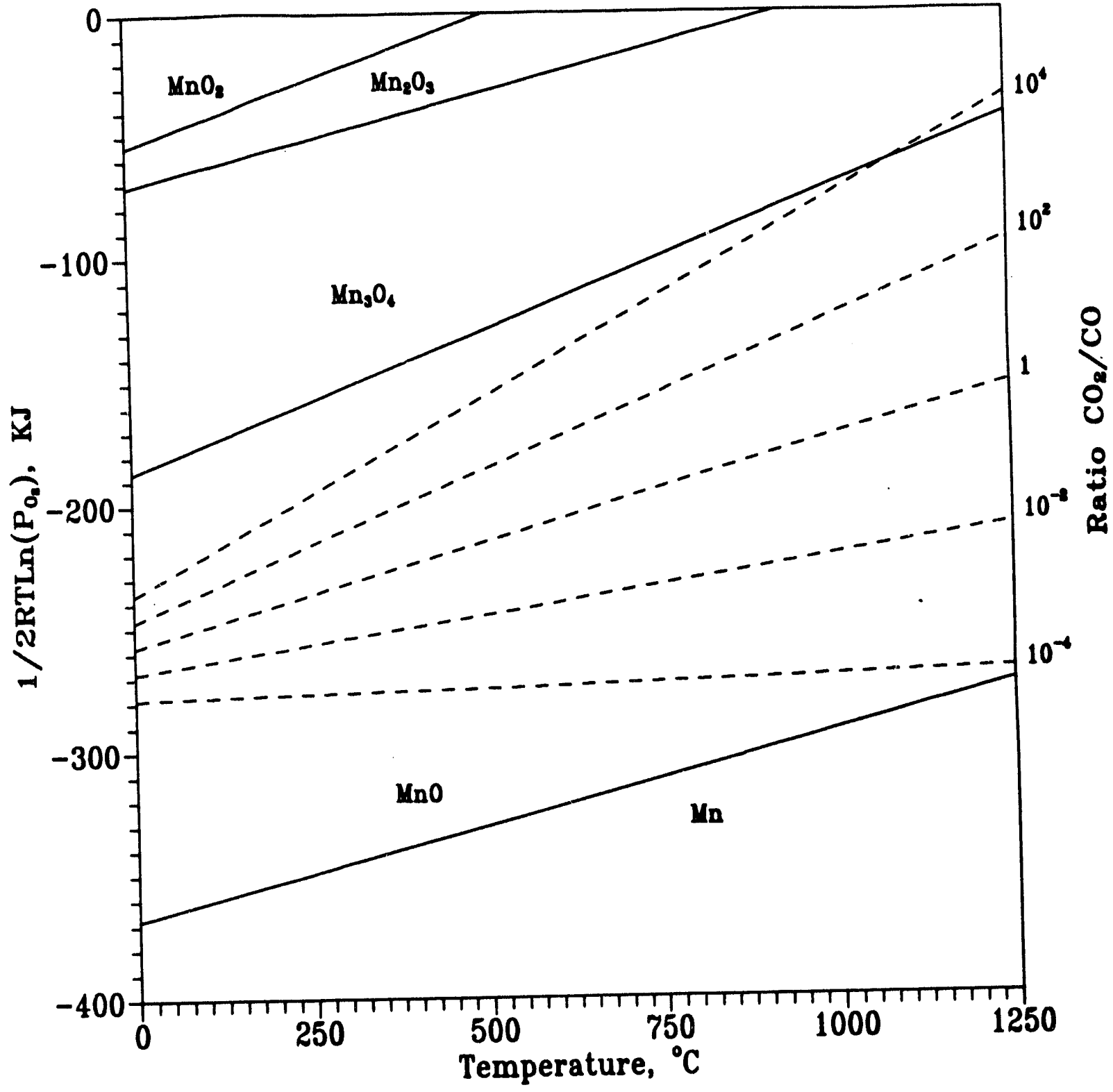

Figure 1. Stability Diagram of Mn-O System as a Function of Oxygen Potential $\left(\mathbf{P}_{\mathrm{CO} 2} / \mathbf{P}_{\mathbf{C O}}\right)$ and Temperature 


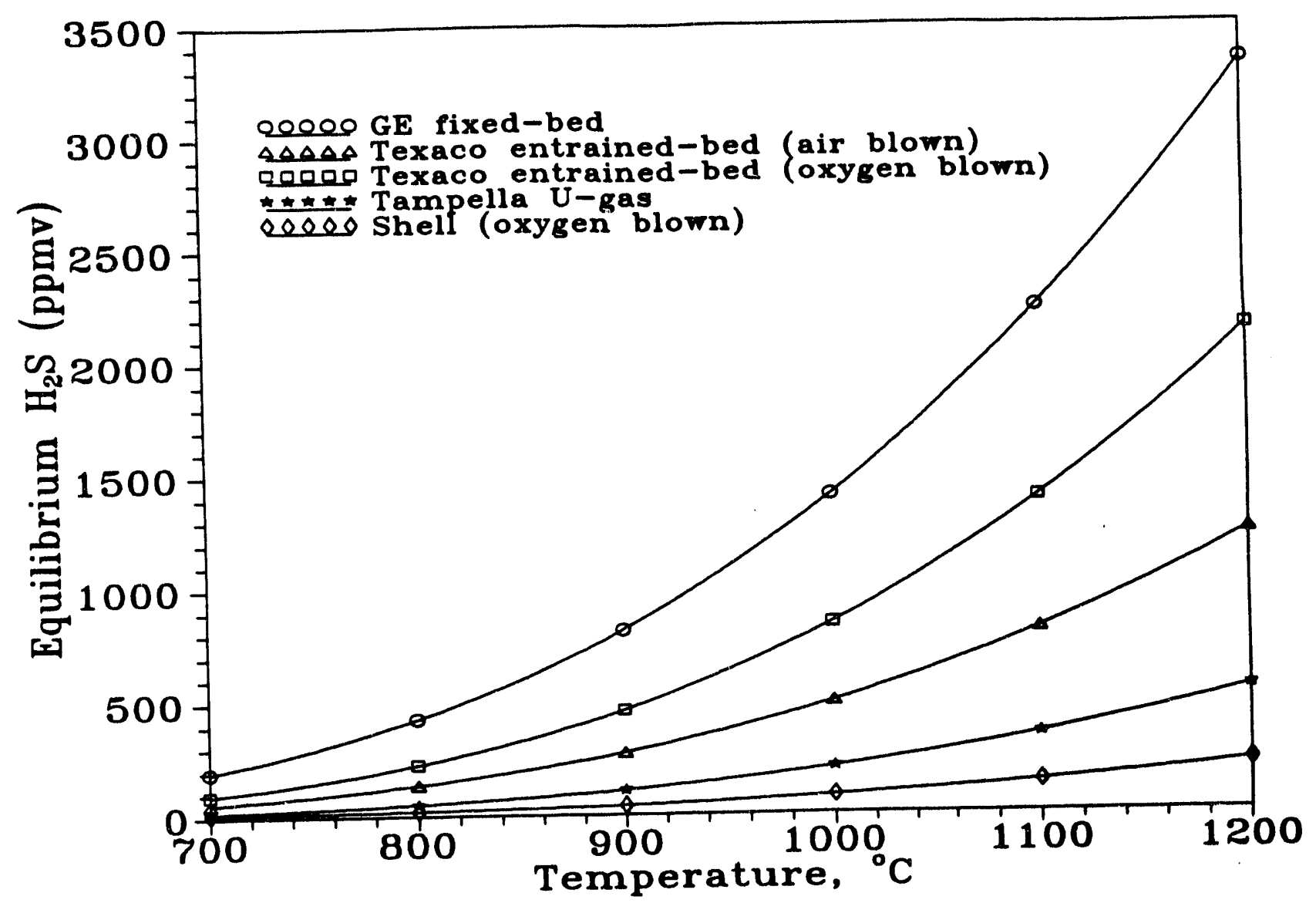

Figure 2. Equilibrium $\mathrm{H}_{2} \mathrm{~S}$ Concentration in Desulfurized Gas as a Function of Temperature for Typical Air-Blown and Oxygen-Blown Gasifiers 

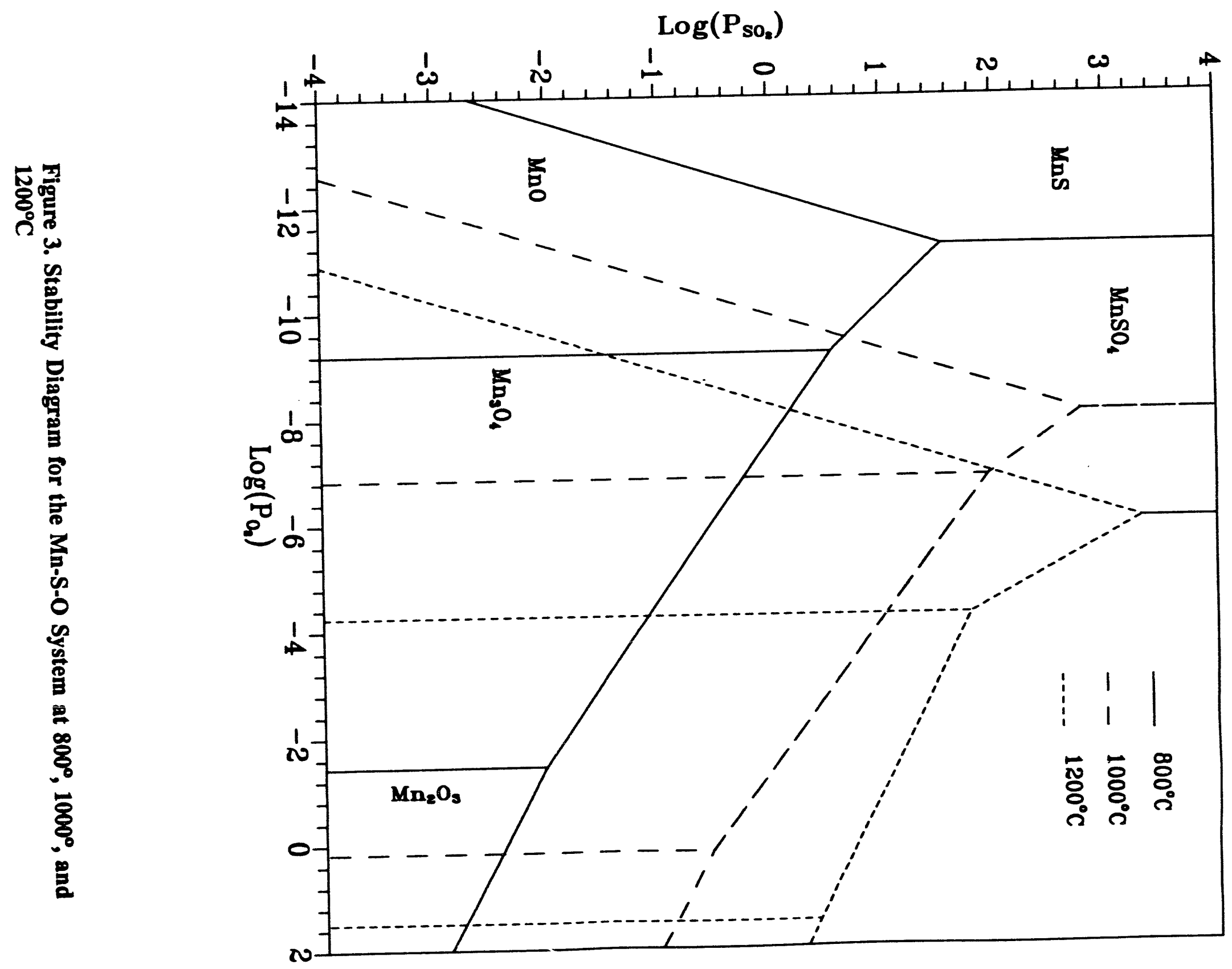


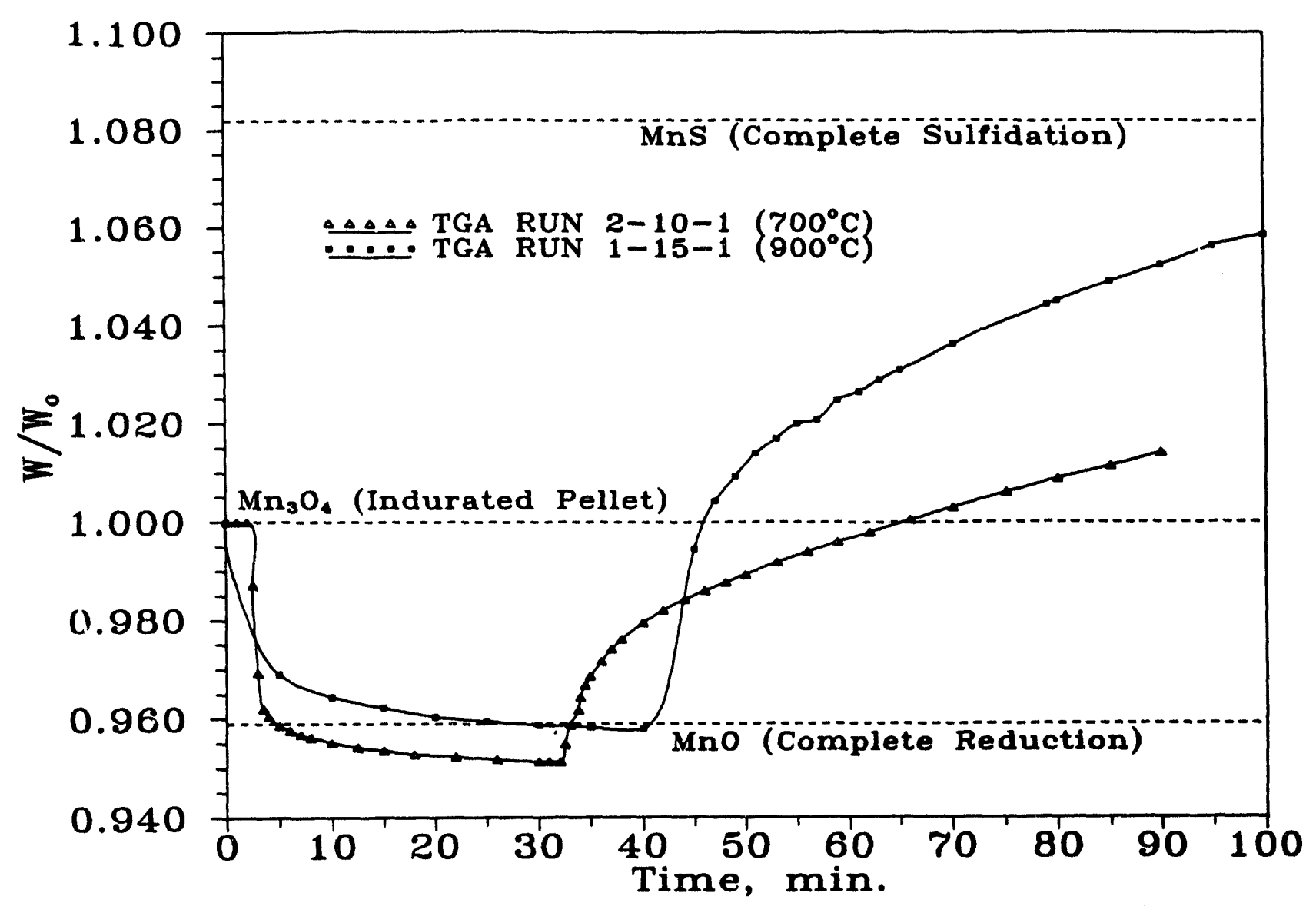

Figure 4. Kinetics of Loading on Formulation 2 via TGA at $700^{\circ}$ and $900^{\circ} \mathrm{C}$ 


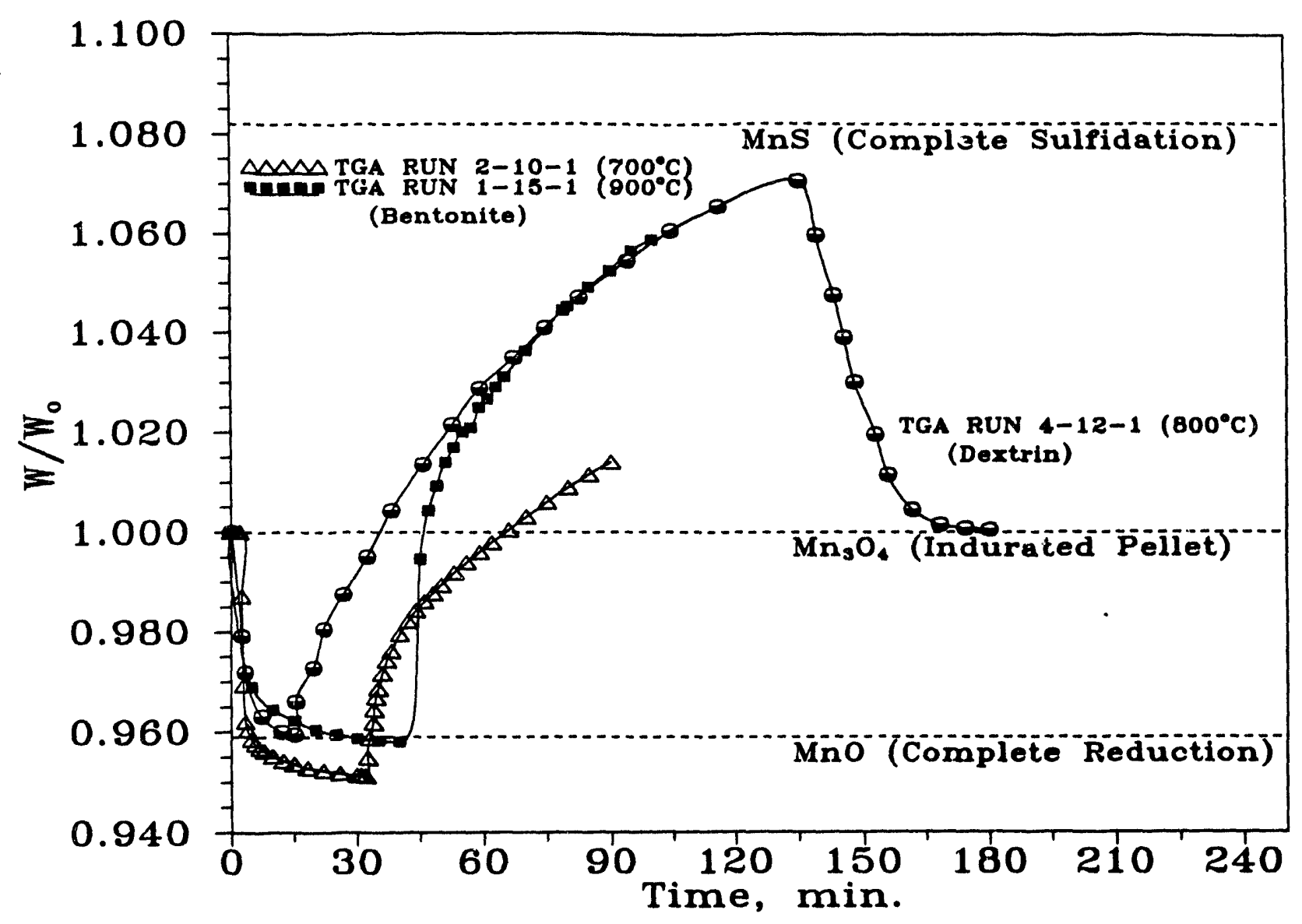

Figure 5. Kinetics of Loading at two Temperatures for Formulation 2 Compared with Loading and Regeneration Using Formulation 1 


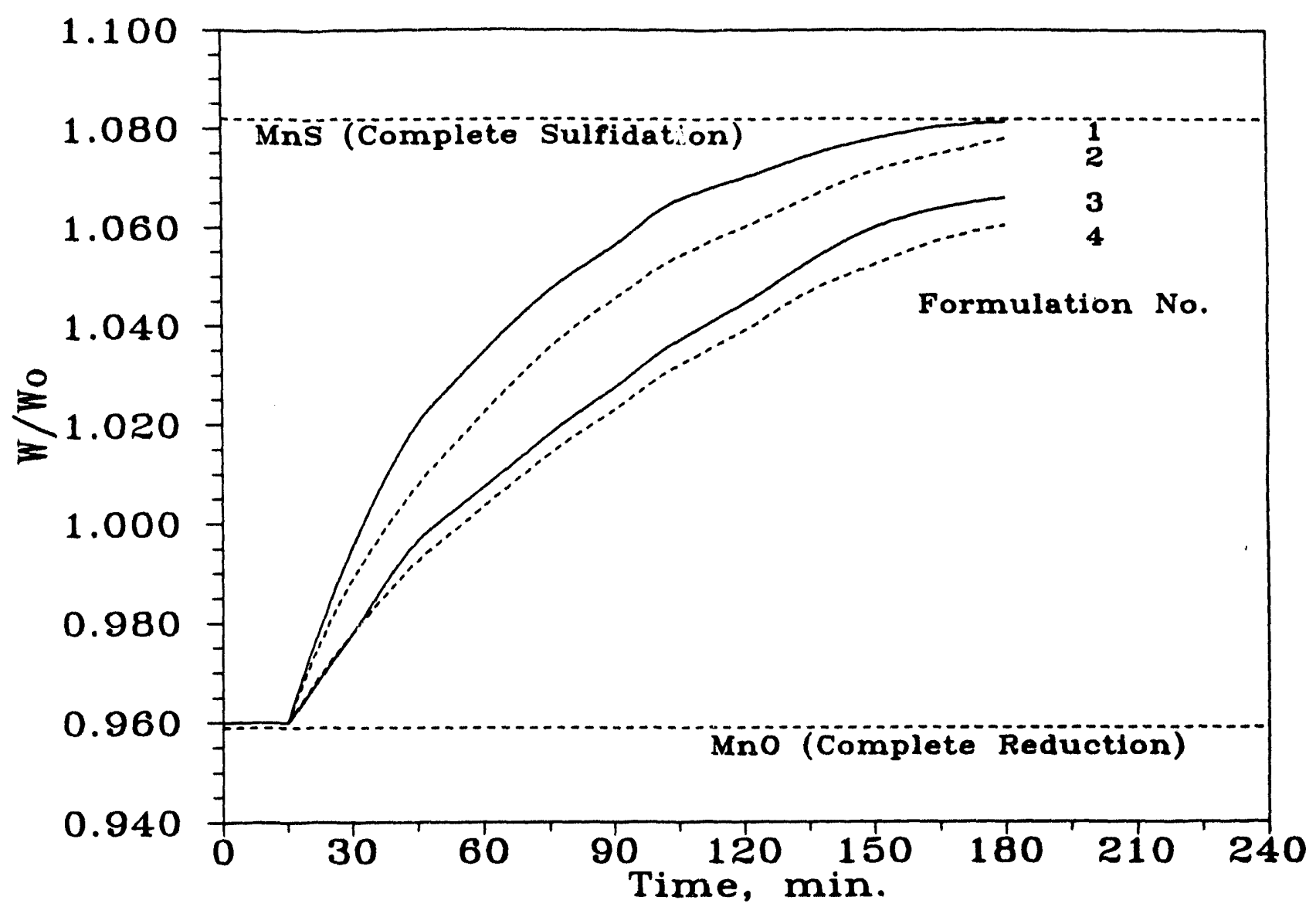

Figure 6. Comparative Loading Kinetics for Four Formulations at $800^{\circ} \mathrm{C}$ 


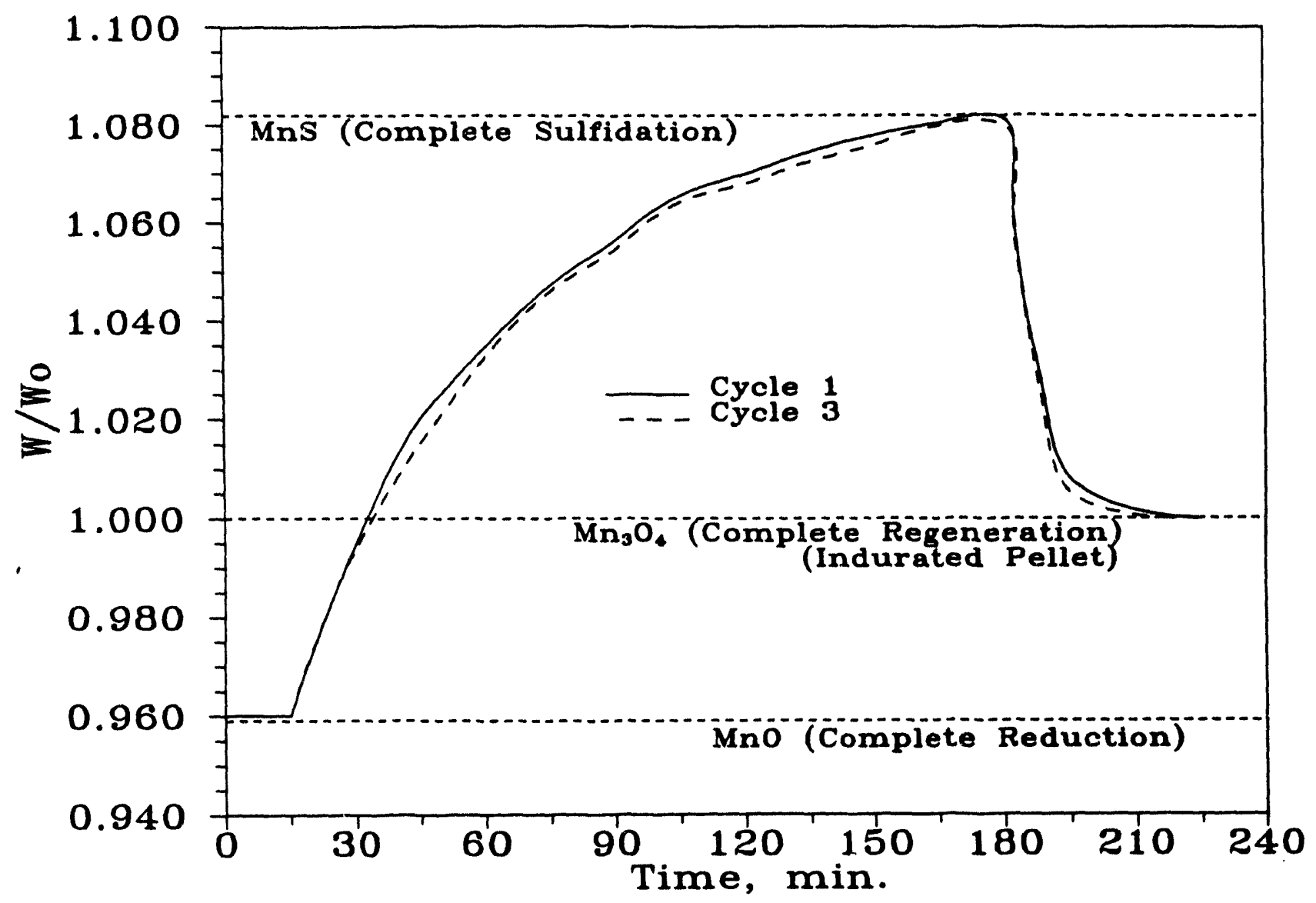

Figure 7. Tests on Cyclic Loading $\left(800^{\circ} \mathrm{C}\right)$ and Regeneration $\left(1050^{\circ} \mathrm{C}\right)$ for Formulation 1 
Appendix A. Typical Gasifier Exit Gas Compositions (Vol.X): (Typical Air-Blown Gasifier: GE G) KRH Fluid-Bed (B \& F), Texaco Entrained-Bed (C\& H), and Lurgi Fixed-Bed (D), Tampella U-Gas (I); and Typical Oxygen-BTown Gasifiers: Texaco Entrained-Bed (J) and Shell (K).

\begin{tabular}{|c|c|c|c|c|c|c|c|c|c|c|c|}
\hline (Vol.\%) & A & B & C & D & $E$ & $F$ & G & H & I & $\mathbf{J}$ & $K$ \\
\hline CO & 8.00 & 10.55 & 16.13 & 11.90 & 40.00 & 15.0 & 8.0 & 15.25 & 24.33 & 39.10 & 64.0 \\
\hline $\mathrm{CO}_{2}$ & 11.0 & 4.64 & 7.55 & 10.00 & 12.50 & 5.0 & 11.0 & 8.28 & 5.16 & 12.25 & 0.8 \\
\hline $\mathrm{H}_{2}$ & 16.0 & 8.26 & 10.70 & 17.40 & 27.84 & 10.0 & 15.0 & 10.79 & 13.19 & 30.13 & 31.6 \\
\hline $\mathrm{H}_{2} \mathrm{O}$ & 30.0 & 27.52 & 10.94 & 28.10 & 18.50 & 15.0 & 30.0 & 10.76 & 5.35 & 17.52 & 1.5 \\
\hline $\mathrm{H}_{2} \mathrm{~S}$ & 3.00 & 0.28 & 0.42 & 1.00 & 1.08 & 0.5 & 0.5 & 0.5 & 0.118 & 1.00 & 1.4 \\
\hline $\cos$ & -- & -- & 0.03 & --- & 0.08 & -- & -- & --- & -- & -- & --- \\
\hline $\mathrm{N}_{2}$ & 29.0 & 48.73 & 54.22 & 28.70 & -- & 53.7 & 32.2 & 53.92 & 49.90 & -- & 0.7 \\
\hline $\mathrm{CH}_{4}$ & 3.00 & 0.24 & --- & 3.00 & --- & 0.5 & 3.0 & --- & 1.84 & --- & --- \\
\hline $\mathrm{NH}_{3}$ & 0.50 & 0.02 & 0.1600 & 0.500 & 0.200 & 0.3 & 0.3 & --- & 0.111 & -- & -- \\
\hline $\mathrm{CO} / \mathrm{CO}_{2}$ & 0.73 & 2.27 & 2.14 & 1.19 & 3.20 & 3.00 & 0.73 & 1.84 & 4.72 & 3.19 & 80.0 \\
\hline $\mathrm{H}_{2} / \mathrm{H}_{2} \mathrm{O}$ & 0.53 & 0.30 & 0.98 & 0.62 & 1.50 & 0.67 & 0.50 & 1.00 & 2.47 & 1.72 & 21.0 \\
\hline
\end{tabular}
Research Triengle Institute. 
APPENDIX B

Assays of Raw Materials

1) "Moanda" Comilog Ore (African Manganese Dioxide Ore): Received from: The Prince Manufacturing Company.

Typical Chemical Analysis of Comilog Ore

\begin{tabular}{|c|c||c|c|c|c||}
\hline Species & Wt.\% & Species & Wt.\% & Species & Wt.\% \\
\hline $\mathrm{Mn}$ & 51.2 & $\mathrm{P}$ & 0.109 & $\mathrm{~S}$ & 0.019 \\
\hline $\mathrm{MnO}_{2}$ & 77.0 & $\mathrm{Co}$ & 0.099 & $\mathrm{~V}$ & 0.012 \\
\hline $\mathrm{MnO}$ & 3.36 & $\mathrm{CaO}$ & 0.08 & $\mathrm{As}$ & 0.007 \\
\hline $\mathrm{Al}_{2} \mathrm{O}_{3}$ & 6.01 & $\mathrm{Zn}$ & 0.064 & $\mathrm{Cr}$ & 0.006 \\
\hline $\mathrm{Fe}$ & 2.81 & $\mathrm{MgO}$ & 0.06 & $\mathrm{Mo}$ & 0.006 \\
\hline $\mathrm{SiO}_{2}$ & 2.56 & $\mathrm{Ni}$ & 0.058 & $\mathrm{~Pb}$ & 0.004 \\
\hline $\mathrm{K}_{2} \mathrm{O}$ & 0.71 & $\mathrm{Cu}$ & 0.05 & $\mathrm{H}_{2} \mathrm{O}$ (bound) & 5.16 \\
\hline $\mathrm{BaO}^{\mathrm{TiO}}$ & 0.22 & $\mathrm{CO}_{2}$ & 0.04 & & \\
\hline $\mathrm{Na}_{2} \mathrm{O}$ & 0.04 & & \\
\hline
\end{tabular}

2) Alundum Fepa F, Size 600, Code 7102

Received from: Norton Industrial Ceramics Corporation

Typical Chemical Analysis

\begin{tabular}{|c|c|c|c|c|c|c|c|c|}
\hline Species & $\mathrm{Al}_{2} \mathrm{O}_{3}$ & $\mathrm{TiO}_{2}$ & $\mathrm{SiO}_{2}$ & $\mathrm{Fe}_{2} \mathrm{O}_{3}$ & $\mathrm{CaO}$ & $\mathrm{MgO}$ & $\mathrm{S}$ & $\mathrm{K}_{2} \mathrm{O}$ \\
\hline Wt. & 96.60 & 2.60 & 0.60 & 0.20 & 0.10 & 0.40 & 0.02 & 0.02 \\
\hline
\end{tabular}

3) Manganese Carbonate: Received from Chemetals, Inc.

This product contains approximately 93-958 $\mathrm{MnCO}_{3}$; no typical analysis is available at the present time. 

